Proceedings

\title{
Native Bees Are Important and Need Immediate Conservation Measures: A Review ${ }^{\dagger}$
}

\author{
Amarjit S. Tanda *
}

Citation: Tanda, A.S. Native Bees Are Important and Need Immediate Conservation Measures: A Review, in Proceedings of the 1st International Electronic Conference on Entomology, 1-15 July 2021, MDPI: Basel, Switzerland, doi:10.3390/IECE10523

Published: 1 July 2021

Publisher's Note: MDPI stays neutral with regard to jurisdictional claims in published maps and institutional affiliations.

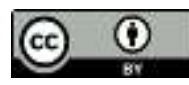

Copyright: (c) 2021 by the authors. Submitted for possible open access publication under the terms and conditions of the Creative Commons Attribution (CC BY) license (http://creativecommons.org/licenses /by/4.0/).

\author{
School of Horticulture University of Western Sydney Richmond Australia, CSIRO, Australia; \\ drtanda101@gmail.com \\ * Current Address 2/49 Arthur Street Rose hill NSW 2142 Australia \\ + Presented at the 1st International Electronic Conference on Entomology (IECE 2021), 1-15 July 2021; \\ Available online: https://iece.sciforum.net/.
}

\begin{abstract}
Field crops rely on managed and wild bee pollinators, raising concerns about world food security. In North America alone, 4,000 native bee species, provide over US $\$ 1.5$ billion each year from bee pollinated crops. Wild entpollinatology constitute a great part of bio-diversity. In US, the nationwide annual production value of wild pollinators was estimated over $\$ 1.5$ billion; the worth of wild bee pollination in insect pollinated crops would be much more. Pollinator declines could translate directly into reduced production in many crops, and that wild species contribute substantially to pollination of most crops. By pollinating just a handful of crops, wild bees contribute over $\$ 1.5$ billion annually.In this article, after realizing the significance of wild bees, we highlight to manage wild native bee pollinators to act as co-actors to honey bees in enhancing the global crop production.
\end{abstract}

Keywords: wild bees; bio-diversity; pollinators; crop; improvement; yield; buzz pollination; management; ecosystem; sustainability; habitat.

\section{Introduction}

All over the world, wild bees are the chief pollinators, being responsible for the pollination, seed setting and fruit production of many field crops. Over the last few decades, being an ignored part of bio-diverse system, they have been suffering from a worldwide decline mostly created by agricultural interferences. Bee scientists are now worried for the immediate and effective actions to conserve the native bees for using in crop pollination, environment in food production and for the sustainable bio-diverse system. People's interest in the bee protection enhanced greatly, thanks to the number of research reports broadcasted on the TV, radio and newspapers (Schatz, 2020; Tanda, 2019, $2021 a, b, c)$. Few less-charismatic creatures sometimes remain unknown from human acknowledgement (Hart and Sumner, 2020), encouraging bee pollinator conservation is an easier topic to educate a large group of people. However, as this subject appears to be already known to many people, a lack of information and comprehension of the interest is flagrant and thus having a space between knowledge and its comprehension (Wilson et al., 2017). This pause is due to the absence of understanding about the hoverflies and butterflies biodiversity. In Great Britain and the United States 80\% and 99\% of survey reports assert that bees are chief players (Wilson et al., 2017). Generally, people understood the honeybee Apis mellifera, as the main pollinators. Further, the pollination technology, the significance of flower assets and nesting site environment, major groups of pollinators with specific needs are also significant. This lack of knowledge could therefore guide to irrelevant steps for the conservation of endangered insect pollinators (Wilson et al., 2017; Schatz, 2020; Penn, 2021; Tanda, 2019, 2021a,b,c). The distortion of reports 
presented by media, can even emphasize these unsuitable measures. The knowledge of people has not developed with the growth of scientific information on this subject. For entomologists, species identification and naming endangered bees is demanding and a topic of deep studies (Didham, 2020). Harvey et al., (2017) developed a plan for pollinator's protection and their retrieval as a foundation for all the apiculturists. The population of all terrestrial insect species has declined by $9 \%$ for the last 10 years and the native bees cannot be excluded from the list (van Klink et al., 2020). Reports on the illeffects of environment on the abundance of native bees are plentiful (Potts et al., 2010; Goulson et al., 2015; Tanda, 2019, 2021a, b, c). To ease their deleterious impacts, the national and regional actions has been more linked with the execution of pollinator conservation methods since many years. Such protection measures carried out provincially are of great significance in the protection of native fauna. Several bees are endangered locally and facing disappearance, but still survive in their geographical habitat (Primack et al., 2012). This event can be noted by looking at European and IUCN Red Lists studies (IUCN, 2016). In Belgium, several native bees are under threat or even disappeared locally but their abundance is not absent at the European scale (Drossart et al., 2018). This report describes the effectiveness of protection activities at different geographical areas. Ignorance of the objective is flagrant and it discloses a pause between consciousness and the scientific understanding (Wilson et al., 2017). This gap is generally delineated by an ignorance of information about the prominent abundance of bees, hoverflies, and butterflies in the functional ecosystem. In Great Britain and the United States respectively, about $80 \%$ and $99 \%$ of survey reports assert that bees are valuable, but only $3 \%$ and $14 \%$ can evaluate the pollinators spread in their terrestrial regions (Wilson et al., 2017). Many people are capable to recognize honeybees and bumblebees crop pollinators, however the other native bees are poorly identified as main species. Less than $50 \%$ of the participants were even unable to name at least one bee worker (Wilson et al., 2017). Through huge presentations, chiefly targeted on the honeybee Apis mellifera, the general public was aware of the crop pollination value, but not the occurrence and its immensity. Among the audience, the value of flowers, bee nesting sites, suitable habitat and the existence of different major groups of bee pollinators with their specific needs were also not well known. This ignorance of scientific information could therefore may encourage to unrelated measures, wrong, or even inefficient actions for the conservation of endangered bee species (Wilson et al., 2017; Drossart and Gerard, 2020). It is obvious that with the scientific knowledge, the public awareness has not enhanced. So for apiculturists, bee identification and prioritizing endangered species is challenging and a major project to ongoing research and an enlightening plan for wild bee conservation and their recovery system to be framed. About $9 \%$ terrestrial insect populations per decade has perished and the wild bee abundance are also not an anomaly (van Klink et al., 2020). On wild bee populations, reports on the harmful impact of stressors are in plenty (Potts et al., 2010; Goulson et al., 2015; Tanda, 2019, $2021 \mathrm{a}, \mathrm{b}, \mathrm{c})$. Noting the deleterious environmental impacts, decrease in the bee abundance, national and regional initiatives related with the wild bee fauna conservation and their protection actions should be executed at the earliest. In the conservation of native bee biodiverse system, all the possible preservation steps will be of paramount significance. To be sure, as numerous bees are threatened locally and face geographical disappearance, they may still survive quite long within their overall regional ranges (Schatz, 2020; Penn, 2021; Tanda, 2021). Such occurrences can be noticed for instance by collating regional IUCN Red Lists and the European scale reports (IUCN, 2016). In Belgium, several bees are endangered or even nearly disappeared at a regional level as their abundance are not engaging at European level (Drossart et al., 2018). No doubt, the bee abundance ranking as well as the declining elements are greatly studied, still knowledge on the preservation measures of wild bees is not well established. A general and up-to-date evaluation of the conservation actions, technology as well as their effectiveness and efficiency, is still wanting. Keeping this in mind, firstly, we reviewed the significance of preserving native bees, bee population's assessments at risk alongwith the factors associated with declining their 
abundance. Secondly, we concentrated on the conservation actions, related factors, and the effectiveness of these measures. Finally, we emphasized on the preservation actions that enhance the bee-friendly environment including semi-natural landscapes to urban and agricultural habitats marking the required floral and nesting sites, and alien species with habitat control process. To top off the many spaces of native bee protection, some recent projects and studies have been presented here.

\section{Wild bee conservation is for global food sustainability?}

Bees being the main flower pollinators in many bio-environments, pollinators are involved in the propagation of $80 \%$ of angiosperms (IPBES, 2016). Due to this breeding technology, crosspollination is contemplated as one of the most crucial jobs in the working of bio-diverse system and boosting in crop production globally (IPBES, 2016; Potts et al., 2016). About $85 \%$ of field crops benefit from insect pollination service that directly influences the quality and quantity of food production (IPBES, 2016) which is worth 100 to 500 billion euros annually all over the world (Lautenbach et al., 2012). The decline in wild insect pollinators is compelling a move in humans to non-pollinator reliant crops for food and facing lack in important nutrients, causing economic and health problems (IPBES, 2016; Potts et al., 2016; Bauer and Wings, 2016). Native wild bees can be the principal pollinators in population in few field crop productions (IPBES, 2016), while other crops are pollinated by commercial honeybees. Only a little bee population forage on crop plants. So, pollination management alone is not sufficient to uphold true alone for the preservation of native bees. Wild bees are also of specific significance due to their capability to visit flowers in a different type of climatic conditions and environment (Brittain et al., 2016). Bumblebees are all-rounder and can visit on flowers at cold conditions and are also capable of foraging even at high sonication frequently. Apparently, in wild flora, the high specialty and wide diversity of native pollinators builds up a complementary and synergistic action with managed honeybees (Fründ et al., 2013; Garibaldi et al., 2014; Isaacs et al., 2017). Grab et al., (2019) has described this in the phylogenetic diversity and bee abundance associated with crop pollination. On the same time, working bee diversity also work like a chief player to enhance the crop yield (Martins et al., 2015). Also, in the urban (Säumel et al., 2016), forests (Cummings et al., 2016), and natural bio-environments (Cummings et al., 2016; Massaro et al., 2013), the important role of native bees has also been established and their abundance is related to the wild floral density (Ollerton, 2017). Ecological interaction extinction in bees and flowers, is ignored frequently instead of the bee disappearing assessment (Valiente-Banuet et al., 2015). Still, this loss of biodiversity element happens same time or may lead up to extinction of the bee pollinator (ValienteBanuet et al., 2015; Jacquemin et al., 2020). Many bee pollinators are very firmly associated to a specific environment and food resorts, which make them tolerate that habitat and food upsetting. Specialist species visit on a few flowers whereas all-rounder pollinators have wide range of flower foraging options (Jacquemin et al., 2020). Thus the generalists are more tolerant to the different climatic conditions associated with human activities as they are capable to manage on other food assets (Roger et al., 2017). Damage of these biotic interplay effect in rapid species disappearances and negatively influence the working of the eco-bio-structure (Diaz et al., 2017). To avoid the collapse in environmental services to humans, the importance of interplay of biotic agents be contemplated (Jacquemin et al., 2020) to assess the fitness of environment and to determine the possible environmental matters (Aizen et al., 2012; Dirzo et al., 2014). In Andalucía BeeFun project, is focusing on the improvement of knowledge and comprehension of the influence of environment, bee crop-pollination system and social units (Underwood et al., 2020; Drossart and Gerard, 2020).

\section{Possibilities in species extinction and their studies}


Studies and assessment of bee population technology needs a basic action for global fluctuations in the decline and benefit of the bee species. In this worldwide transformation, a few species can survive or finish as described in the United Kingdom (Powney et al., 2020). IUCN Red List technology guides to assess the possible extinction of a bee species at regional, national, and global levels (IUCN, 2016) and there may be variations in the assessment techniques in different environments. To establish a fundamental base for the preservation actions and assessment of the species to execute monitoring, conservation strategy, management and policy formation, this is the most powerful technology. Red List for wild bees, at European level and many more nations are also preparing their own Red Lists at country and regional level (Drossart et al., 2018; Reemer et al., 2018). At continental scale, in North America, IUCN has also undertaken the efficiency evaluation for the Bombus spp. (Hatfield et al., 2020). This research knowledge for wild bees aids in spotlighting the abundance, bee species, and regions more in danger. Conservation programs and strategies also calls to register factors menacing the abundance of wild bee species (Harvey et al., 2020; Primack et al., 2012; IPBES, 2012). Scientists are aiming at the extent of decline and factors accountable for the population retreat (Forister et al., 2019). Besides fire, drought, hydrological and geophysical events having a non-negligible influence on native pollinators (Nicholson et al., 2019), global warming, crop escalation, habitat and diseases greatly influence the bee populations (Potts et al., 2010; IPBES, 2016). Either effect of single element (Potts et al., 2010) and expected feasible interactions (Goulson et al., 2015; Meeus et al., 2018) have been reported in many countries, still a big scientific information space remains in the measurement of the spatial and temporal impacts from the various dangers alongwith the historical reports separately (Bartomeus et al., 2019). Furthermore, the knowledge of the genetic variation in species, population dynamics and speciation are also important and more and more utilized in conservative biological aspects (Epps and Keyghobadi, 2015). Recent studies in genetic conservation has permitted the workers to manipulate molecular biotechnology to know better about bee bio-diversity (Epps and Keyghobadi, 2015; Lopez-Uribe et al., 2017), with new gene bio-techniques also appearing (Woodard et al., 2016). This is quite apparent in cryptic species of bumblebees possessing high degree of morphological confluence. Less genetic diversity which can result in inbreeding depression and lessen the health is alarming (Packer et al., 2016). Depending on historical processes reports and distance assessments (IBD), the evaluation of the linkages among bee abundance, their efficient part of population and their biotic and abiotic operators, researchers can rank the endangered species (Cerna et al., 2017; Lecocq et al., 2017, 2018). Using various tools and the assessment of the threatening elements, through population assessments scientists are now capable of conservation tactics by policy agreements, applied plans, and actions with ongoing studies (van Klink et al., 2020; Forister et al., 2019; Drossart and Gerard, 2020).

\section{Conservation technology and players}

After knowing the population tendencies and decline operators, then important action is to protect the suitable environments. In fact, based upon the scale and the landscape, there is a great wild bee heterogeneity and population diversity (Belsky and Joshi, 2019). Native bee make-up is framed by landscape fitness globally, from mountainous tropical habitats of Colombia (Cely-Santos and Philpott, 2019) to dry grasslands in Missouri, USA (Grover et al., 2017). Grasslands with blossoms provide a great bee abundance and habitats than crops devoted to livestock and full of flowers. So to protect such suitable habitats can be attained by the development of safe areas using legal actions to avoid any changes, and by buying such important ecosystems. Adaptive management of bee pollinators and habitats, in such preserved regions, have to be established to elucidate the best programs and adaptive activities for the victories and failures of the bee management practices. Nevertheless, several anthropogenic habitats of cities can never provide the same extent of bee shelter than the semi-natural environments, but still need conservation steps. To achieve such dreams, many joint plans aiming at the presentation of habitats, 
biodiversity intensification, minimum invasive of alien bees or the communication about diversity loss have been adopted from the World Bee Project. The World Bee strategy targets to amalgamate cloud computing with wild bee studies globally to serve all new intuitions and information to develop strategies for global bee decline, different climatic conditions and increased food sustainability and subsistence to intercontinental extent combinig other plans carried out by the European Union (EU, 2011) executed at national level (Belgian NFP-CBD, 2020) and at other various scales to check the pollinators decline in USA (Heinz Center,2013); in France, Gadoum and Roux-Fouillet, 2016); in Ireland, (PPSG, 2015). Some private groups such as Bee and Butterfly Habitat Fund, Seeds for Bees, and The Dutch Bee Strategy, the English National Pollinator Strategy are supporting to convene stakeholders to share their experiences and work collectively from different backgrounds (Saunders et al., 2018; Turo and Gardiner,2019). To keep going such programs, public suggestions and the involvement of young boys is crucial (Turo and Gardiner, 2019). We suggest that main efforts should be concentrated on the safety, preservation and the restoration of native bee habitats, concentration on the urban and agricultural fields, and execution of man-made devices to offer nesting sites, potential invasions by alien species and the education and training of people with effective transmission.

\section{Preservation and restoration of native bee habitats}

In the beginning, native bee preservation can be carried out by the conservation of semi natural habitats to rebuild huge natural environments committed to bio-diverse system. Bee environment is most important in the decline and protection of terrestrial insects in the safety of habitat (van Klink et al., 2020). Such environments are diverse techniques to explain: the most common attempt to take into consideration the prominent distinct diverse ecosystem (Sobral-Souza et al., 2018). These dynamic modules can be evaluated by Ecological Nich Models (Krechemer and Marchioro, 2020) as utilized in many bumblebee populations in South-America. Similar restored ecological environments can boost native bee populations in landscapes and geographic wide ranges (Tonietto and Larkin, 2018). Improvement of the environment by repairing techniques implicit an investigation of the habitat of the target species. They evaluated the preferences of bumblebee likings in the crops and suggested natural landscapes and field boundaries for the bee population survival. Wild bees can react differently in changed environments. Carrié et al., (2017) reported that grasslands, hedgerows, and forest edges with positive preferred traits e.g. solitary and ground-dwelling bees foraging a large variety of plants, while the social and above ground nesting bees and those foraging a narrow range of blooms minimized in such environments. As in Brazil, more area of rainforest could enhance above-ground nesting wild species, conversely (Ferreira et al., 2015) indicating the significance of conservation technology, in a restored bee-ecosystem. Furthermore, the restoration tools can be double-edged and are often circumstance reliant. As grazing and burning are followed in grasslands to aid floral blooming, however they can also destroy wild bees hibernating in the plants (Tonietto and Larkin, 2018). These restoration measures are conducted in the framework of LIFE plans funded by the European Union. They focus to renovate bee habitats directed in Natura 2000 bee sites mentioned in "Birds" and "Fauna-Flora-Habitats". In case bee protection stay at its infancy compared to birds and mammals safekeeping, focus as pollinators as butterflies and LIFE in Quarries will indirectly benefit to native bees with the conservation and the renovation of habitats as in peat bogs, quarries, high value biological meadows, and hedgerows (Folschweiller et al., 2019). As LIFE dedicating plans are not active, Urbanbees LIFE programs are emerging (www.urbanbees.eu) and are focusing at the framing of management directions to sustain and enhance the population and diversity of native bees in potential habitats of urban and peri-urban. Bee conservation minus plans is also noticeable at the political level. For instance, Hall and Steiner( 2019) mentioned that US state schemes generally did not consider the importance of bee pollinators in comparison to vertebrates resulting in poor comprehension of their needs, and restoration actions. Some protection programs aim on bee pollinators in semi-natural 
environments for instance reservoirs are considered in plans at national/sub-national level; such initiatives should be executed in future protection schemes of endangered populations.

\section{Bee protection actions in human environments}

Many instances of Urban and Agricultural Areas Conservation measures are important in anthropogenic regions as more than $55 \%$ of the wild bee species survive in periurban habitats (UN, 2020). Generally, the mono-culturing technology is reported to decrease the native bee population and the bio-diverse system (Kennedy et al., 2013). As these habitats need food resources and nesting sites, immediate actions should be taken in deeply urbanized and arduously managed environments. Amalgamating eco-economic expenses and logistical profits, their regulation can be modified and thus enable the improvement of these ignored habitats. Restoring environments near to locations with huge anthropogenic influence could therefore work as a safeguard for native bee abundance. Accordingly, few measures are being taken for example, guides encouraging the development and control of bee pollinator suitable environments in cropping areas using practicable recommendations (Nowakowski and Pywell, 2016; Gosselin et al., 2018). Under such important programs, hedgerows, parks, roadsides, and urban gardens can constitute crucial environments for bee multiplication in quality and quantity, and transitional areas as beneficial environment (Hall et al., 2017; Crone et al., 2019). Similar habitats can help in building great specific diversity and an enhancing factor for rare populations (Senapathi et al., 2017) and often pillar a great bee diverse ecosystem (Fortel et al., 2014). Bee-friendly plans using roof-top gardens, parks, and roadsides, has enhanced the populations of native bees in Amsterdam (Givetash, 2018) as this environmental interconnection proved important ecological segmentation could be harmful for little bee species. To be sure, the size of body is frequently correspond with spreading capabilities. In segmented environments, tiny bees can be incompetent to access the favorable landscapes and get hardships in anthropogenic habitats Warzecha et al., 2017; Gérard et al., 2019). In urbanization or intensive farming, these components permitting relationship in protected environments offering dwelling locations and flower food assets (La Vie Sauvage, 2020; François and Féon , 2017). Theoretical structure about the significance of the interconnecting factors, has not yet been assessed empirically. It is important if we initiate research on the effectiveness of these protective actions.

Besides, from urban habitats, protection plans in agroindustry have still established a positive influence, relying on the kind of actions, the taxa selected and the make-up of countryside biodiversity. Preservation measures in such environment is pivotal as about $40 \%$ of land utilization is loyal to agriculture sector globally (Ritchie and Roser, 2020). Protection of flower assets is one of the most usual action to protect native bee anthropogenic environments. It has been revealed largely that strength of floral wealth is a key framework for native bee diversity, when renovating prairies as in Minnesota, USA (Lane et al., 2020). Nevertheless, many actions can only influence a narrow bio-diverse system and happen at local level. Agro-habitat measures, for example strips of flowers have been admitted in Europe to enhance biodiversity in arduously managed agro-landscapes Grass et al., 2016; Cole et al., 2020) and beneficial for bumblebees, honeybees, and hoverflies in Germany, Belgium, and in England (Wood et al., 2015). More flower supplies often helped in the improvement of bumblebee abundance, size, density and young ones number (Wood et al., 2015; Vaudo et al., 2018). The influence of AES was rarely assessed (Batáry et al., 2015) and Geppert et al., (2020) measured the impact of organic cropping and floral strips for bee population survival. Both actions were positively corresponding to pollinators' strength and population and growth of bumblebee hives, but the efficiency of these actions relied firmly on the landscape around (Geppert et al., 2020). In England, (Wood et al., 2017) also assessed a Higher Level Stewardship farms - HLS to experiment if grown flowers helped the native solitary bee populations. They reported that $30 \%$ of the bees found in the trial region efficiently visit on planted flowers from agri-environment seed 
mixtures, thus directing to conceive the structure of seed mixes if we are interested to support diverse wild bee populations. Relying on the habitat kind and the species of plant re-established, wild bee family will indeed exihbit various reactions. For instance, as honeybees and bumblebees were positively influenced by the affair of Phacelia sp., solitary bees mostly foraged sunflower and seed mixes of wildblooms (Mallinger et al., 2020). Reports in Great Britain established that seed mixes grown in agricultural landscapes had a great ratio of clovers Trifolium sp. (Fabaceae), which is very alluring to bumblebees, but not 240 species of solitary bees (Nichols et al., 2019). This compares with the greatness of various pollinator populations required to improve the pollination services in the bee environment (Garibaldi et al., 2013). So the option of plant mixes rely on the targeted species for protection. These agro-environmental actions helpful to a reduced number of bee pollinator have been designed to basically meet the economic benefits of the agroindustry for fixed income and are derived from the requirements of bee largely utilized in crop production. Besides, it appears that the studies undertaken in this frame and has provided a recommendation for the preservation of all target crop pollinators in the National Pollinator Strategy (DEFRA,2020). Still, a move in flower resources happened among the most environments of native bees facing stress and could result in the exhaustion of flower assets and alterations in crop-pollinator web (Gérard et al., 2020). Further, the plant preference in floral mixtures has thus to be totally reframed, because this option is followed by research related to the foraging frequency of honeybees and bumblebees. The restructuring of flower mixtures could also be effective in bee environments with maximum flower density in areas under crop and uncultivated land (Quinet et al., 2016; Moquet et al., 2017). Still, habitat preservation specialists need knowledge about the empirically measured actions; their preferences are thus often determined by the actions helpful from chief profitoriented promotions. Angiosperms should offer the flow of floral gifts throughout the flowering season for sufficient food needs (Vaudo et al., 2015; Filipiak et al., 2018) based on the floral phenology and specific behavior of bee species. Gresty et al., (2018) demonstrated that plants like Rosa canina, Malva sylvestris, and Ranuncula acris allured specifically those solitary bees living in cavities. So, several native flower seed mixes do not meet the needs of cavity-dwelling solitary native bees as they do not have these species. Available plants should also fulfil the nutrient requirements of species too. This framework is pivotal for bee multiplication and abundance but is often neglected during the selection of bee-friendly flowering plant cultivars. Especially, this is accurate for the brood nutritional needs, which vary from adult requirements (Filipiak et al., 2018). The strength and nutritional power of crops like Brassica napus for Osmia bicornis) can positively help in development rate of bee abundance (Bukovinszky et al., 2017; Filipiak, 2019). In fact, the variety of proteins and essential amino acids required is important for the growth and development of bee population. To prevent nutritional shortages, the eco-stoichiometry can be measured by the atomic allowances of $\mathrm{C}, \mathrm{K}, \mathrm{P}, \mathrm{N}$ and $\mathrm{Na}$ for the growth of brood. The information on such ratios is not yet studied and need to be tested in a plant family largely, however, are being undertaken by the biodivERsA NUTRIB2 research plan (2020-2023). This can help bee species health through nutritional needs using floral assets available in the habitats, particularly in flower resource exhausted environments. Different agrotechnology could also be tested such as friendly planting, which can enhance the quantity and quality as in the strawberry Fragaria $x$ ananassa and the borage Borago officinalis, (Griffiths et al., 2020) but the effect on pollinator abundance was not studied. Regarding chemical sprays, most of the reports show their effects on honeybees and many bumblebees' species and knowledge about their sub-lethal and lethal effects on native bees are deficient. There could be synergism, however this needs to be undertaken (Tosi and Nieh, 2019). Bumblebees ingest minimum chemical dose per gram as compared to honeybees due to their bigger size (Gradish et al., 2019). They also forage two or three times more blossoms, working in a wide range of environment, their larvae are offered with pollen and nectar in raw gathering maximum pollen than honeybee immature stages. So it is difficult to describe the chemical toxicity taken from reports on honeybees and generalize about bumblebees 
and solitary bee taxa, furthermore, solitary bee's sensitivity will be highly different (Biddinger et al., 2013). POSHBEE, European strategies could be beneficial comprehending that how pesticides can influence these native bee fauna and synergistic effect with other decline elements. The safeguard principle is suggested mostly and different for pesticides by restored processes can be beneficial to this change. Utilization of few plant essential oils or the evolution of new biomolecules focusing at the management of plant diseases related to biodiversity (Interreg SMARTBIOCONTROL plans, http://www.smartbiocontrol.eu/) could constitute precious alternative measures. We should also to study the time for less sprays and use of bio-pesticides (Biddinger et al., 2018). Integrated Pest Management Technology (IPMT) is promoted as a blend of different suitable techniques to alleviate the negative impacts of rigorous agro management practices on native bees. Still, it has been demonstrated to also influence bee pollinators and is not a particular reaction to safeguard bee world Dicks et al., 2016; Egan et al., 2020). Egan et al., (2020) demonstrated a newly designed strategy that is known as Integrated Pest and Pollinators Management (IPPM; Biddinger and Rajotte, 2015) the same we propose to be called as "Integrated Pest and Pollinators Management Technology" (IPPMT) where we blend various techniques to manage pest problems in crops alongwith flower pollinating players. We suggest different actions to avert touching measure doorsteps for pest and crop pollinators, remedial actions once the measure thresholds have been exceled. Applied management actions, are also recommended as the choosing of varieties with great bee pollinator allurement and maximum pest resistance. Advance new programs should be started to design sustainable plans in crop landscapes at different geographical degrees. In fact, crop environments are landscapes where many new programs help in offering solutions. As European EcoStack H2020 program focus on evolving and helping sustainable food production and preservation strategies (PPS) by contemplating major ecological, economic and sociological features to boost sustainability in the programs of food production in Europe. In Ireland, The Protecting Farmland Pollinators plan is reliant upon the designing of a crop bee pollinator assessing campaign which can permit growers to determine simply which control processes on agro lands help to pollinators in decreased pesticides usage, offer little environments and floral resources for example, flowering pattern at the farmland level. This plan is for boosting of the cropping structure quality by the execution of measures permitting to biodiversity to exist together. Growers begin a decent chain of reactions for habitat, and the protection of future bee populations. Additionally, the Interreg-Sudoe Poll-Ole-GI project (2016-2019) focused recognizing and suggesting efficient practices as green infrastructures (GI) to positively effect on bee pollinator abundance and bee ecosystem amenity in the two most significant Mediterranean crops of arable farmland in the South-western European Space (SUDOE) which comprises Southern France, Spain, and Portugal, including sunflower and oilseed rape (https://pollolegi.eu/).

\section{Arranging wild bee nesting sites}

Good work has been done to enhance the accessibility of flower assets for bee pollinators in reports, however, hardly few observations have aimed at the other important subject of bee dwelling sites (Fortel et al., 2016). Actually, few efforts have concentrated on the abiotic components effecting nesting victory and location choice by various bee species (Sardiñas and Kremen, 2014). Endangered bee species could be established in soilnesting and other wild bees with special nesting conduct, nesting in cavities, underground, carder bees and shells of snails. We suggest profuse nesting provisions, comprising the establishments of Wild Bee Inns for the living of little bee pollinators species on a widely spread areas. Fortel et al., (2016) demonstrated the utilization of 21 species, including 17 Megachilids, by arranging insect hotels in urban regions. This constitutes less than $10 \%$ of the species strength found in the same region, as 248 insect species reported in 16 urban and peri-urban locations. Maclvor and Packer (2015) also described the possibilities of this new bee renovated environmental enlargement plans for native bee requirements. They spotlighted that about $50 \%$ of bee population lodged in the bee hotels were newly 
inducted exotic bees, however $75 \%$ of them were inhabited by wasps. Geslin et al., (2020) also reported more inhabitation rate i.e., $40 \%$ of all individuals in 96 bee hotels by the exotic Megachile sculpturalis. More alarmingly, they reported a negative interrelationship between the wild bees and the presence of this insect species in bee hotel arrangements. Besides, bee hotels it could also ease in the transference of insect diseases, as another future problem (Maclvor and Packer, 2015). The reports concluded that this protection technology maybe not as helpful as was expected before (Maclvor and Packer, 2015). Fortel et al., (2016) assessed 6 types of hypogean nesting, using different soil textures in ground squares to test their utilization for similar studies. However, various soil textures were unable to impact species strength, and in these soil squares, 37 insects were found belonging to Andrenidae and Halictidae. About $20 \%$ of the species were recorded in the region, out of 248 only 57 species occupied the artificial inns (Fortel et al., 2016). This report revealed the positive response of artificial devices for the nesting of native bees, and also shows the role of expanding nesting sites to multiply numerous bee species for the crop pollination services. In fact, focus should be on the existing and bee hotels cavities hole diameter as required by different bee species for nesting, as small diameters could help many wild species and averted by bigger exotic bees like $M$. sculturalis to occupy bee hotel lodging (Geslin et al., 2020). May this be the little patches of bare soil installations, bee inns or the bee hotel lodging arrangements, the practical use of their positive contribution should be thoroughly investigated.

\section{Management of alien plant species}

Additionally the local plant species that can be managed by professionals using protection tactics, many alien species can invade and populate bee-friendly environments, or even they are grown voluntarily. These invading alien plants can have various types of impacts on wild bee populations, it may be positive, neutral, or even negative effect. However, the influence of alien plants can rely on many ecological factors or life history characteristics, resulting in, few species to suffer from the incursions whereas for other it can be beneficial (Davis et al., 2018; Drossart and Gerard, 2020). Usually, an invasion only happens when an exotic species with invasive power experience an adequately suitable habitat. Actually, the responsiveness of bio-environments to invasions is different and is impacted in specific by the disturbance levels and the availability of minerals and elements that impact competition procedures (Davis et al., 2018). This happens when plants are eliminated after a mechanical disruption or when an exogenous stock of nutrients incites eutrophication. This is associated with invasion process and would result in gross destruction of the plant life. Mostly such plant species have established in environments nearly related with human life. In Europe, about $64 \%$ of naturalized exotic plants are observed in areas of industry, 58.5\% in parks gardens, and farmland, $37.5 \%$ in lawn area, and $31.5 \%$ in forests and woods. Affected habitats related to humans, invasive plants can offer food resources for some bee pollinators and improve crop production through pollination services (Hobbs et al., 2013; Drossart et al., 2017; Jachuła et al., 2020). In Ohio, USA, Trifolium repens and Trifolium pratense helped in restoring native bee abundance in urban environments (Hanley et al., 2014; Sivakoff et al., 2018). They may have harmful effects on particular bee species with small diet pliability. However, few unwanted alien plants contend (Van Kleunen et al., 2010) with local vegetation and can oust plants that are visited by particular bee pollinators. Few non-indigenous species also exhibit resources that are unreachable to most of wild bee pollinators e.g., Petunias sp., (Lowenstein and Minor, 2016). Thus, preservation actions to control alien plants could be implemented accordingly to the habitat and the precautionary measures. They could be the elimination of the invasive plants to the management of this population. Majewska and Altizer (2018) demonstrated in a meta-analysis, that no planned positive or negative effect on pollinator population could be ascribed to exotic species and that their influence is case-specific. It can be hypothesized that all exotic species are detrimental is thus as harmful to the knowledge magnification as is the principle that these species are safe (Boltovskoy et al., 
2018). In view of invasive pollinators, their presence can result in the food competition, nesting sites and spread of diseases directly or food web modification and structuring of plant populations' impacts indirectly. The Asian hornet Vespa velutina, for instance, could be a challenge for wild or managed bee pollinators in the future (Arca et al., 2014; Keeling et al., 2017; Laurino et al., 2020). Escaped alien bumblebees utilized for crop pollination is also a developing anxiety. In fact, the result of the bumblebee development are increasingly identified as a main issue for the biodiversity of the world (Sutherland et al., 2016). In Japan, the addition of Bombus terrestris in non-native geographical area can also bring about mating with wild species and production of non-viable offspring in B. hypocrita and B. ignitus. The introduction of Bombus terrestris and B. ruderatus in South America, has brought about the reduction of B. dahlbomii, and the disease spread (Aizen et al., 2019). As many nations has banned the bumblebee alien species trade, these schemes have not always been evenly used. In importation plans, organized international actions to prevent bio-invasions of alien species should thus be a main important issue. Observing of invasive species should be kept on top of the measures, it could permit to acquire the data required to carry out the population dynamics studies and test their potential influence on native species and eco-environments (Le Féon et al., 2018). A law to prevent and alleviate the harmful effects of alien species, in the European Union came into force in 2015 (EU Regulation (EU) No. 1143/2014). It describes a bundle of preventive and curative actions applicable to the 66 species registered. In Europe, execution of strict actions focused on avoiding, minimizing and alleviating the ill-effects of these aliens using a complete, organized, and efficient response to the issue of bio-invasions. Measures were established on close cooperation among all the States having Membership and increased collaboration with non-governmental organizations, economic sectors, and people groups. Assessing the IUCN Red Lists, a parallel program known as "Black List" has been suggested for invasive alien species and contemplates the extent of climatic effect for the species tested (Blackburn et al., 2014). It comprises species with moderate, major, and severe climatic impact. The IUCN Invasive Species Specialist Group (ISSG) gathers specialists in the minimizing challenges created by aliens to native habitats and the species they restrain by enhancing awareness, elimination, manage, or removal pertaining to them. Each group is accountable adapted nationally, making and improving invasive species list in their respective country.

\section{Maintaining wild bee populations-an ultimate measure}

From the scientific information and the effectiveness of preservation actions, liaise more effectively and correctly scientific reports to large audience is a foundation to set up solid conservation starting point. Saunders et al., (2020) described how we should communicate to assist between consciousness and comprehension. They demonstrated the significance to utilize terminology and clear ideas in communication, by stating the taxonomic and geographic level alongwith objective and reports of a research plan. Few precedents in education, training and communication can be defined to strengthen the insect conservation technology (Saunders et al., 2019). It is important to establish human natural world study schemes alongwith education and training using long-term scientific knowledge. In various taxa, maximum use of citizen sciences in bee conservation procedures permitted monitoring population studies over a long time period (Gardiner and Didham, 2020; Ubach et al., 2020). Large number of people paid attention to wild bee pollinator's conservation in the last few years. Despite notable biases in reports, such as observing the most striking and colorful insect species, cryptic species incorrect identification, using this tool, permits to effectively note a large number of specimens in wider area, showing an important part of the species in an environment and assessing the species dynamics for scientific studies (Duchenne et al., 2020) and Red Lists program (Ward, 2014). The establishment of citizen sciences can also be advocated by the evolution of new conservation technology permitting correct insect specimen identification. Then, an advance scientific knowledge of the people is directly connected to the development 
education and training strategies to boost the significance of natural bio-history and the information for students and flora executives. Silva and Minor (2017) established that the degree of education and knowledge about wild bees were directly associated to the positive attitudes of the respondents towards the native bee abundance, encouraging the pivotal role of people consciousness. The media ethics design of education for entomologists and bio-ecologists in order to frame clear transmission aimed at scientific technology and procedures is crucial. Such important research topics and their influence directly on the people in the preservation of biodiversity should be further investigated. This presentation should be shared widely in scholarly literature, and social media in groups and also true in demonstrating the geographic and taxonomic extent of reports (Saunders et al., 2019). People only know about bees by honey, hives and bee sting which is a big misinterpretation. Recent challenge is about native bees the knowledge related with the idea of bees with pollinators and wild species than with the above given ideas (Schonfelder and Bogner, 2017). One of the main challenges to attain native bee preservation in urban regions is that urban inhabitants require to feel safeguard and get the actions aesthetic if we need to desire for prolonged actions. To prevent destruction and gather funds, the help of citizens is pivotal. In public green spaces, require borders, cut grass, and a cleanliness worldwide. To fix this resident liking, the establishing of areas committed particularly to agro-ecohabitats and setting up of pocket prairies are recommended (Turo and Gardiner, 2019). Additionally, the biodiversity observing offered by these plans, citizens and other stakeholders can notify themselves to undertake efficient conservation measures. In suburban environments, listing suggested plant species encouraging both generalist and specialist wild bees based on their nutritional worth and local circumstances can help residents and local or municipal officials in their preferences. Scientific knowledge favouring different ideas prior to the pesticides, mowing/pruning agenda constitutes a main action to efficiently integrate bee groups pollinators in the management system of all parks, gardens, and flowering patches (Folschweiller et al., 2019). Austria developed many research projects focusing on the positive impact on wild pollinators for the renovation of flowering areas in 20ha using 18 local officials by monitoring native bee populations (Underwood et al., 2017). Apart from this pilot project, they also guided to establish various acceptable green habitats in orchards, road edges, schools, nurseries, and along waterways for bee conservation (Underwood et al., 2017). As now the protection of wild bees, and bio-ecosystems in general is everyone's interest, measures can also be executed by the cooperation of both public and private organizations. In Austria, for instance an alliance was established between an NGO and a supermarket chain for bee conservation measures. Similar joint programs initiated between fruit growers and local city municipalities in Flanders (Belgium) or between a beer brewer, NGO, and public officials to boost the bee conservation strategies (Underwood et al., 2017).

For the last few decades, wild bee populations are decreasing globally mostly by the creations of humans. However, on the same time, public business for their preservation enhanced greatly, through many scientific observations transmitted using media. Despite this large interest, due to the shortage of knowledge and subject comprehension is flagrant and describes a space between consciousness and apprehension. As bee decline is widely investigated, knowledge on conservation actions is still dispersed in the writings. We are away from the preventative concepts and professionals are requesting for efficient methods enhancing native bee abundance and the improvement of habitat standard.

In this appraisal, we present a generalized and modern analysis of the wild bee conservation technology, and their effectiveness in habitats and the latest scientific strategies that attempt to fill up the spaces and design new conservation programs. Aiming at wild bees, we concentrated our main knowledge on (i) the native bee environment preservation and its renovation, (ii) the advance conservation actions in anthropogenic habitats, (iii) the execution of man developed devices, (iv) measures to manage alien species, and (v) how to transmit the ideas in the public correctly and effectively for immediate bee 
benefits. Our article can be regarded as a required enzyme to execute a solid and empirical wild bee conversation measure for world food sustainability.

\section{Conclusions}

In wild bee conservation bio-technology and diversity, the importance of species protection needs specialists to communicate ideas and guidance depending on the studies and proofs found (Primack et al., 2012). Based upon the evaluation of disappearance dangers of species as in IUCN red list and resident scientific observations, species needing immediate conservation actions can be identified. We have spotlighted here that the most important task is to clearly pin point all the species selected for conservation. Actually, they will exihbit various bio-ecological characteristics, flower and nesting sites particular needs that require to be named if they have to be conserved fully. The impact of conservation actions also has to be assessed not only for a particular bio-diverse system and population, but also in relation to bio-ecological and beneficial traits, however such features are mostly disregarded but practical bio-diverse environment is more important in bio-ecosystem studies (Schmitt et al., 2020). Several bee protection measures are often undertaken depending on empirical observations on a specific bee, as honeybees or bumblebees, however, ends of such reports can seldom be refereed as substitute for native solitary bee populations (Wood et al., 2020). The flower preferences in seed mixtures and floral borders clearly shows this as doubtful. As this is well studied that flower assets is a main theme for native bee protection program, most research reports demonstrated that the flowering plant found in the mixes are only visited by a little population of bees. A total of 14 blooming species related to 9 families (e.g., Asteraceae, Apicaeae, Geraniaceae) reported to allure 37 of the 40 bee species found in farming-habitats and would perform $100 \%$ flower trips. However, only two of these species are already included in the sowed mixtures recommended in national strategies for the conservation of pollinators. We believe that first focal point is to totally restructure these mixes keeping in mind the latest findings naming visited flowering plants (Gresty et al., 2018) liking the foraging period of selected wild bee and the food necessities of adults and immature stages (Filipiak, 2019). Till today, this topic is roughly studied at the time of framing new wild bee conservation strategies. Besides, there is an important imbalance between the investigations regarding the bee flora, favorable habitats and safe nesting site provisions. As these significant subjects have to be handled in redesigning the bee conservation plans, further research requires attention to study such crucial subjects more thoroughly, especially in assessing a large area of bee dwelling resources than only bee resorts, hotels which host a very little native bee population. The globe which is progressively anthropogenically-moving forward, different bee flora habitats could be, promptly, an answer to the deficit world food problem. In habitats having little native bee-flora, few alien invaded species can assist bee abundance to recuperate. However, such preferences should be considered depending upon powerful empirical proofs as in New-York a new report demonstrated that several exotic species could mostly assist honeybees better than the native wild bee populations (Urbanowicz et al., 2020). In such anthropogenic habitats, the method to run bee-friendly environments have also to be re-consider, in particular by discovering options to pesticide applications. Dealing with such circumstances, the influence of techniques like IPPMT could be enormously explored for the maximum safety of pollinator's world. Additionally, the overwhelming most environment renovation research is carried out in North America and Europe, which constitute only a little portion of worldly environments occupied by native bees. Similar bee restoring methods could not be prototypical of what should be adopted in other bee habitat having dissimilar landscapes (Tonietto and Larkin 2018; Drossart and Gerard, 2020; Tanda, 2019, 2021) also needs attention. Further investigations should be undertaken to assess conservation methods extensively in rainforest and arctic environments. In gathering applied proofs and facts, the transmission of education and training about wild bees have to be reconfigured. It is a fact that we do not preserve birds by offering henhomes, so we will have to increase our attempts so that the 
beautiful world of bees does not spin around the beehives, honey and other products. To tackle this, we should not ignore to involve work packages in our research studies about the communication of knowledge to various schools and those who are realistically employed to execute conservation measures. These projects are often the ones that are abandoned while they should be the acme of several scientific research studies. In spite of gathering information about bee population challenging elements, we should share, import, away from the preventative concepts as they are generally studied, established, recognized and at least assessed in part (Folschweiller et al., 2019; Tanda, 2019, 2021; Penn, 2021). Now specialists are inviting for measures, which need the immediate key attention (Folschweiller et al., 2019). Research plans as the Interreg SAPOLL project, designing a strategy for wild bee conservation as the chief target or the biodivERsA NUTRIB2 project could support to fill the space. The development of such measures and assemble the various bee conservation players would further strengthen the public consciousness to bee biodiversity and environmental services in bio-ecosystems where people are more detached from the natural bee world for example, the houses, commercial buildings, roads, bridges, and railways (Fortel et al., 2016; Penn, 2021). So here are few measures which can protect the bees as part of a new developing campaign worldwide ;

- Pledge to conserve the bee pollinators and join BEE-SAFE on your piece of land, garden, and the backyard of your company or your rooftops. Partner towns, schools, corporations, and individuals land pieces can be utilized.

- Stop using any pesticides on your garden flowering plants to avoid any chemical contamination to bees. Also check plants you buy are not pre-treated with neonics pesticides.

- In your garden always grow bee pollinator's preferred flowering plants as they are a big asset for bees and butterflies offering nectar and pollen.

- Plant prairies, keep away from lawns as they desert for bee pollinators.

- Never weed your gardens as dandelions are best source of bee food in early spring and medicine for human.

- In every balcony, we can install water basins in summer with pebbles or floating corks on water to prevent bees from drowning.

- Keep in touch with the Facebook page of New York Bee Sanctuary and Instagram account to get enlightened and sign regular petitions to pressurise the world countries to pass laws to conserve the bees banning neonicotinoids.

- Educate and train the public including your family by showing bee documentaries. Native bees are harmless, and visit flowers. Understand their services in food production for the whole world by paying regards.

- Install a bee hive and modified handmade devices for wild bees in your back yard or your rooftops. It's an excellent method to provide home and nesting sites for bee species.

Funding No funding

Conflicts of interest/Competing interests No Conflicts of interest

Availability of data and material there is no additional data

\section{References}

Aizen, M.; Sabatino, M.; Tylianakis, J.M. 2012. Specialization and rarity predict non-random loss of interactions from mutualist networks. Science, 335, 1486-1489.

Aizen, M.A.; Smith-Ramirez, C.; Morales, C.L.; Vieli, L.; Saez, A.; Barahona-Segovia, R.M.; Arbetman, M.P.; Montalva, J.; Garibaldi, L.A.; Inouye, D.W.; et al. 2019. Coordinated species importation policies are needed to reduce serious invasions globally: The case of alien bumblebees in South America. J. Appl. Ecol., 56, 100-106. 
Arca, M.; Papachristoforou, A.; Mougel, F.; Rortais, A.; Monceau, K.; Bonnard, O.; Tardy, P.; Thiéry, D.; Silvain, J.F.; Arnold, G. 2014. Defensive behaviour of Apis mellifera against Vespa velutina in France: Testing whether European honeybees can develop an effective collective defence against a new predator. Behav. Process., 106, 122-129.

Available online: https://www.royalmailgroup.com/en/press-centre/press-releases/royal-mail/royal-mailissues-special-stampsillustrating-the-beauty-of-british-bees/ (accessed on 20 April 2020).

Bartomeus, I.; Stavert, J.R.; Ward, D.; Aguado, O. 2019. Historical collections as a tool for assessing the global pollination crisis. Philos. Trans. R. Soc. B, 374, 20170389.

Batáry, P.; Dicks, L.V.; Kleijn, D.; Sutherland, W.J. 2015.The role of agri-environment schemes in conservation and environmental management. Conserv. Biol., 29, 1006-1016.

Bauer, D.M.; Wings, I.S. 2016.The macroeconomic cost of catastrophic pollinator declines. Ecol. Econ., 126, 1-13.

Belgian National Focal Point to the Convention on Biological Diversity (Belgian NFP-CBD). 2020. Biodiversity 2020-Update of Belgium's National Biodiversity Strategy; Royal Belgian Institute of Natural Sciences: Brussels, Belgium, p. 148.

Belsky, J.; Joshi, N.K. 2019.Impact of Biotic and Abiotic Stressors on Managed and Feral Bees. Insects 10:233.

Biddinger, D.; Rajotte, E.G.; Joshi, N.K. 2018. Integrating pollinator health into tree fruit IPM-A case study of Pennsylvania apple production. In The Pollination of Cultivated Plants: A Compendium for Practitioners, 2nd ed.; FAO: Rome, Italy 1:69-83.

Biddinger, D.J.; Rajotte, E.G. 2015.Integrated pest and pollinator management-adding a new dimension to an accepted paradigm. Curr. Opin. Insect Sci., 10:204-209.

Biddinger, D.J.; Robertson, J.L.; Mullin, C.; Frazier, J.; Ashcraft, S.A.; Rajotte, E.G.; Joshi, N.K.; Vaughn, M. 2013. Comparative toxicities and synergism of apple orchard pesticides to Apis mellifera (L.) and Osmia cornifrons (Radoszkowski). PLoS ONE, 8, e72587.

Blackburn, T.M.; Essl, F.; Evans, T.; Hulme, P.E.; Jeschke, J.M.; Kühn, I.; Kumschick, S.; Marková, Z.; Mrugała, A.; Nentwig, W.; et al. 2014. A unified classification of alien species based on the magnitude of their environmental impacts. PLoS Biol., 12, e1001850.

Boltovskoy, D.; Sylvester, F.; Paolucci, E.M. 2018. Invasive species denialism: Sorting out facts, beliefs, and definitions. Ecol. Evol., 8:11190-11198.

Brittain, C.; Kremen, C.; Klein, A.M. 2013.Biodiversity buffers pollination in changing environmental conditions. Glob. Change Biol. 19: 540-547.

Bukovinszky, T.; Rikken, I.; Evers, S.; Wäckers, F.L.; Biesmeijer, J.C.; Prins, H.H.T.; Kleijn, D. 2017. Effects of pollen species composition on the foraging behaviour and offspring performance of the mason bee Osmia bicornis (L.). Basic Appl. Ecol. 18: 21-30.

Carrié, R.; Andrieu, E.; Cunningham, S.A.; Lentini, P.E.; Loreau, M.; Ouin, A. 2017. Relationships among ecological traits of wild bee communities along gradients of habitat amount and fragmentation. Ecography 40:85-97.

Cely-Santos, M.; Philpott, S.M. 2019. Local and landscape habitat influences on bee diversity in agricultural landscapes in Anolaima, Colombia. J. Insect Conserv., 23:133-146.

Cerna, K.; Munclinger, P.; Vereecken, N.J.; Straka, J. 2017.Mediterranean lineage endemism, cold-adapted paleodemographic dynamics and recent changes in population size in two solitary bees of the genus Anthophora. Conserv. Genet., 18:521-538.

Cole, L.J.; Kleijn, D.; Dicks, L.V.; Stout, J.C.; Potts, S.G.; Albrecht, M.; Balzan, M.V.; Bartomeus, I.; Bebeli, P.J.; Bevk, D.; et al. 2020. A critical analysis of the potential for EU Common Agricultural Policy measures to support wild pollinators on farmland. J. Appl. Ecol., 57:681-694.

Cramner, L.; McCollin, D.; Ollerton, J. 2012. Landscape structure influences pollinator movements and directly affects plant reproductive success. Oikos, 121: 562-568.

Crone, E.E.; Brown, L.M.; Hodgson, J.A.; Lutscher, F.; Schultz, C.B. 2019.Faster movement in nonhabitat matrix promotes range shifts in heterogeneous landscapes. Ecology, 100, e02701.

Cummings, A.R.; Read, J.M. 2016. Drawing on traditional knowledge to identify and describe ecosystem services associated with Northern Amazon's multiple-use plants. Integrative J. Biodivers. Sci. Ecosyst. Serv. Manag., 12:39-56.

Davis, E.S.; Kelly, R.; Maggs, C.A.; Stout, J.C. 2018. Contrasting impacts of highly invasive plant species on flower-visiting insect communities. Biodivers. Conserv., 27: 2069-2085.

DEFRA. 2020. The National Pollinator Strategy: For Bees and other Pollinators in England. Defra Publ.PB14221.Available online: https:/www.gov.uk/government/publications/national-pollinator-strategy-for-bees-andother-pollinators-in-england (accessed on 21 April 2020).

Diaz, S.; Purvis, A.; Cornelissen, J.H.C.; Mace, G.M.; Donoghue, M.J.; Ewers, R.M.; Jordano, P.; Pearse, W.D. 2013. Functional traits, the phylogeny of function and ecosystem service vulnerability. Ecol. Evol., 3:2958-2975.

Dickinson, J.L.; Zuckerber, B.; Bonter, D.N. 2010. Citizen science as an ecological research tool: Challenges and benefits. Annu. Rev. Ecol. Evol. Syst., 41:149-172.

Dicks, L.V.; Viana, B.; Bommarco, R.; Brosi, B.; Arizmendi, M.C.; Cummingham, S.A.; Galetto, L.; Hill, R.; Lopes, A.V.; Pires, C.; et al. 2016.Ten policies for pollinators. Science, 354: 975-976.

Didham, R.K.; Basset, Y.; Collins, C.M.; Leather, S.R.; Littlewood, N.; Menz, M.H.M.; Müller, J.; Packer, L.; Sauners, M.E.; Schönrogge, K.; et al. 2020. Interpreting insect declines: Seven challenges and a way forward. Insect Conserv. Diver., 13:103-114.

Dirzo, R.; Youg, H.S.; Galetti, M.; Ceballos, G.; Isaac, N.J.B.; Collen, B. 2014.Defaunation in the Anthropocene. Science, 345: $401-406$.

Dötterl, S.; Vereecken, N.J. 2010.The chemical ecology and evolution of bee-flower interactions: A review and perspectives. Can. J. Zool., 88: 668-697. 
Drossart, M.; Gerard, M. 2020. Beyond the decline of wild bees: Optimizing conservation measures and bringing together the actors. Insects 11: 649 .

Drossart, M.; Michez, D.; Vanderplanck, M. Invasive plants as potential food resource for native pollinators: A case study with two invasive species and a generalist bumble bee. Sci. Rep. UK 2017, 7:16242.

Drossart, M.; Rasmont, P.; Vanormelingen, P.; Dufrêne, M.; Folschweiller, M.; Pauly, A.; Vereecken, N.J.; Vray, S.; Zambra, E.; D’Haeseleer, J.; et al. 2018. Belgian Red List of Bees; Belgian Science Policy (BRAIN-be-(Belgian Research Action through Interdisciplinary Networks); Presse Universitaire de l'Université de Mons:Mons, Belgium, 2018; p. 140.

Duchenne, F.; Thébault, E.; Michez, D.; Elias, M.; Drake, M.; Persson, M.; Rousseau-Piot, J.S.; Pollet, M.; Vanormelingen, P.; Fontaine, C. 2020.Phenological shifts alter the seasonal structure of pollinator assemblages in Europe. Nat. Ecol. Evol., 4:115-121.

Egan, P.A.; Dicks, L.V.; Hokkanen, H.M.T.; Stenberg, J.A. 2020.Delivering Integrated Pest and Pollinator Management (IPPM). Trends Plant. Sci., 25:577-589.

Eilers, E.J.; Kremen, C.; Greenleaf, S.S.; Garber, A.L.; Klein, A.M. 2011.Contribution of pollinator-mediated crops to nutrients in the human food supply. PLoS ONE, 6, e21363.

Epps, C.W.; Keyghobadi, N. 2015. Landscape genetics in a changing world: Disentangling historical and contemporary influences and inferring change. Mol. Ecol., 24:6021-6040.

European Union. 2011. The EU Biodiversity Strategy to 2020; Office of the European Union: Luxembourg,; 28p, ISBN 978-92-7920762-4.

Ferreira, P.A.; Boscolo, D.; Carvalheiro, L.G.; Biesmeijer, J.C.; Rocha, P.L.B.; Viana, B.F. 2015. Responses of bees to habitat loss in fragmented landscapes of Brazilian atlantic rainforest. Landsc. Ecol., 30:2067-2078.

Filipiak, M. 2018. A better understanding of bee nutritional ecology is needed to optimize conservation strategies for wild bees-the application of ecological stoichiometry. Insects, 9:85.

Filipiak, M. 2019. Key pollen host plants provide balanced diets for wild bee larvae: A lesson for planting flower strips and hedgerows. J. Appl. Ecol., 56:1410-1418.

Filipiak, M.; Kuszewska, K.; Asselman, M.; Denisow, B.; Stawiarz, E.; Woyciechowski, M.; Weiner, J. 2017. Ecological stoichiometry of the honeybee: Pollen diversity and adequate species composition are needed to mitigate limitations imposed on the growth and development of bees by pollen quality. PLoS ONE, 12, e0183236.

Folschweiller, M.; Drossart, M.; D’Haeseleer, J.; Marescaux, Q.; Rey, G.; Rousseau-Piot, J.S.; Barbier, Y.; Dufrêne, M.; Hautekeete, N.; Jacquemin, F.; et al. 2019. Plan d'action transfrontalier en faveur des pollinisateurs sauvages. In Projet Interreg V SAPOLLSauvons nos Pollinisateurs-Samenwerken voor Pollinators; Université de Mons: Mons, Belgium,; p. 147. ISBN 978-2-87325-1185.

Forister, M.L.; Pelton, E.M.; Black, S.H. 2019.Declines in insect abundance and diversity: We know enough to act now. Conserv. Sci. Pract., 1, e80.

Fortel, L. 2014. Ecologie et Conservation des Abeilles Sauvages le Long d'un Gradient D'urbanisation. Ph.D. Thesis, Université d'Avignon et des Pays du Vaucluse, Avignon, France.

Fortel, L.; Henry, M.; Guilbaud, L.; Guirao, A.L.; Kuhlmann, M.; Mouret, H.; Rollin, O.; Vaissiere, B.E. 2014. Decreasing abundance, increasing diversity and changing structure of the wild bee community (Hymenoptera: Anthophila) along an urbanization gradient. PLoS ONE, 9.

Fortel, L.; Henry, M.; Guilbaud, L.; Mouret, H.; Vaissiere, B.E. 2016. Use of human-made nesting structures by wild bees in an urban environment. J. Insect. Conserv., 20:239-253.

François, D.; Le Féon, V. 2017.Abeilles sauvages et dépendances vertes routières, Pourquoi et comment developer la capacité d'accueil des dépendances vertes routières en faveur des abeilles sauvages. In Ouvrages Scientifiques, OSI2; Ifsttar: Marne-la-Vallée, France,; p. 120. ISBN 978-2-85782-733-7.

Fründ, J.; Dormann, C.F.; Holzschuh, A.; Tscharntke, T. 2013.Bee diversity effects on pollination depend on functional complementarity and niche shifts. Ecology, 94:2042-2045.

Gadoum, S.; Roux-Fouillet, J.M. 2016. Plan National D'actions «France Terre de Pollinisateurs » Pour la Préservation des Abeilles et des Insectes Pollinisateurs Sauvages; Office Pour les Insectes et leur Environnement-Ministère de l'Écologie, du Développement Durable et de l'Énergie: Paris, France,; p. 136.

Gardiner, T.; Didham, R.K. 2020. Glowing, glowing, gone? Monitoring long term trends in glow-worm numbers in south-east England. Insect Conserv. Diver., 13:162-174.

Garibaldi, L.A.; Carvalhiero, L.G.; Leonhardt, S.D.; Aizen, M.A.; Blaauw, B.R.; Isaacs, R.; Kuhlmann, M.;Kleijn, D.; Klein, A.M.; Kremen, C.; et al. 2014.From research to action: Enhancing crop yield through wild pollinators. Front. Ecol. Environ., 12 : $439-447$.

Garibaldi, L.A.; Steffan-Dewenter, I.; Winfree, R.; Aizen, M.A.; Bommarco, R.; Cunningham, S.A.; Kremen, C.;Cavalheiro, L.G.; Harder, L.D.; Afik, O.; et al. 2013.Wild pollinators enhance fruit set of crops regardless of honey bee abundance. Science, 339:1608-1611.

Geppert, C.; Hass, A.; Földesi, R.; Donko, B.; Akter, A.; Tscharntke, T.; Batary, P. 2020. Agri-environment schemes enhance pollinator richness and abundance but bumblebee reproduction depends on field size. J. Appl. Ecol.

Gérard, M.; Martinet, B.; Maebe, K.; Marshall, L.; Smagghe, G.; Vereecken, N.J.; Vray, S.; Rasmont, P.; Michez, D. 2019.Shift in size of bumblebee queens over the last century. Glob. Chang. Biol., 26:1185-1195.

Gérard, M.; Vanderplanck, M.; Wood, T.J.; Michez, D. 2020. Global warming and plant-pollinator mismatches. Emerg. Top. Life Sci. 
Geslin, B.; Gachet, S.; Deschamps-Cottin, M.; Flacher, F.; Ignace, B.; Knoploch, C.; Meineri, E.; Robles, C.; Ropars, L.; Schurr, L.; et al. 2020. Bee hotels host a high abundance of exotic bees in an urban context. Acta Oecol., 105:103556.

Gibbs, J.; Elle, E.; Bobiwash, K.; Haapalainen, T.; Isaacs, R. 2016.Contrasting pollinators and pollination in native and non-native regions of highbush blueberry production. PLoS ONE, 11, e0158937.

Givetash, L. 2018. Bees are Dying at an Alarming Rate. Amsterdam May Have the Answer. NBC News, 7 September. Available online: https://www.nbcnews.com/news/world/bees-are-dying-alarming-rateamsterdammay-have-answer-n897856(accessed on 15 July 2020).

Gosselin, M.; Moerman, R.; Terzo, M.; Vereecken, N.; Rasmont, P. 2018. Abeilles sauvages, bourdons et autres insects pollinisateurs. In Collection Agrinature no 9; Service Public de Wallonie: Namur, Belgium,; p. 155.

Goulson, D.; Nicholls, E.; Botias, C.; Rotheray, E.L. 2015. Bee declines driven by combined stress from parasites pesticides, and lack of flowers. Science, 347, 1255957.

Grab, H.; Branstetter, M.G.; Amon, N.; Urban-Mead, K.R.; Park, M.G.; Gibbs, J.; Blitzer, E.J.; Poveda, K.;Loeb, G.; Danforth, B.N. 2019. Agriculturally dominated landscapes reduce bee phylogenetic diversity and pollination services. Science, 363: $282-284$.

Gradish, A.E.; van der Steen, J.; Scott-Dupree, C.D.; Cabrera, A.R.; Cutler, G.C.; Goulson, D.; Klein, O.; Lehmann, D.M.; Luckmann, J.; O'Neill, B.; et al. 2019. Comparison of pesticide exposure in honey bees (Hymenoptera: Apidae) and Bumble Bees (Hymenoptera: Apidae): Implications for Risk Assessments. Env. Entomol., 48:12-21.

Grass, I.; Albrecht, J.; Jauker, F.; Diekötter, T.; Warzecha, D.; Wolters, V.; Farwig, N. 2016. Much more than bees-Wildflower plantings support highly diverse flower-visitor communities from complex to structurally simple agricultural landscapes. Agric. Ecosyst. Environ., 225:45-53.

Gresty, C.E.A.; Clare, E.; Devey, D.S.; Cowan, R.S.; Csiba, L.; Malakasi, P.; Lewis, O.T.; Willis, K.T. 2018. Flower preferences and pollen transport networks for cavity-nesting solitary bees: Implications for the design of agri-environment schemes. Ecol. Evol., 15:7574-7587.

Griffiths, J.; Nicholls, E.; Goulson, D. 2020. Companion planting to attract pollinators increases the yield and quality of strawberry fruit in gardens and allotments. Ecol. Entomol.

Grover, S.N.; Miller, J.E.D.; Damschen, E. 2017. Indirect Effects of Landscape Spatial Structure and Plant Species Richness on Pollinator Diversity in Ozark Glades. Castanea, 82: 24-31.

Hall, D.M.; Camilo, G.R.; Tonietto, R.K.; Ollerton, J.; Ahrné, K.; Arduser, M.; Ascher, J.S.; Baldock, K.C.R.; Fowler, R.; Frankie, G.; et al. 2017.The city as a refuge for insect pollinators. Conserv. Biol., 31: 24-29.

Hall, D.M.; Steiner, R. 2019.Insect pollinator conservation policy innovations at subnational levels: Lessons for lawmakers. Environ. Sci. Policy, 93, 118-128. 97. United Nations. United Nations, Department of Economic and Social Affairs. Available online: https://www.

Hanley, M.E.; Awbi, A.J.; Franco, M. 2014. Going native? Flower use by bumblebees in English urban gardens. Ann. Bot. Lond., 113:799-806.

Hart, A.G.; Sumner, S. 2020. Marketing insects: Can exploiting a commercial framework promote undervalued insect species? Insect Conserv. Diver., 13:214-218.

Harvey, J.A.; Heinen, R.; Armbrecht, I.; Basset, Y.; Baxter-Gilbert, J.H.; Bezemer, T.M.; Böhm, M.; Bommarco, R.; Borges, P.A.V.; Cardoso, P.; et al. 2020. International scientists formulate a roadmap for insect conservation and recovery. Nat. Ecol. Evol., 4:174-176.

Hatfield, R.; Colla, S.; Jepsen, S.; Richardson, L.L.; Thorp, R.W.; Jordan, S.F. 2020. IUCN Assessments for North American Bombus ssp. for the North American IUCN Bumble Bee Specialist Group. The Xerces Society for Invertebrate Conservation. Available online: https://xerces.org/sites/default/files/publications/14-065.pdf (accessed on 18 August 2020).

Hobbs, R.J.; Higgs, E.S.; Hall, C. 2013. Novel Ecosystems: Intervening in the New Ecological World Order; John Wiley \& Sons: New York, NY, USA.

IPBES. 2016.The Assessment Report of the Intergovernmental Science-Policy Platform on Biodiversity and Ecosystem Services on Pollinators, Pollination and Food Production; Potts, S.G., Imperatriz-Fonseca, V.L., Ngo, H.T.,Eds.; Secretariat of the Intergovernmental Science-Policy Platform on Biodiversity and Ecosystem Services:Bonn, Germany,; p. 552.

Isaacs, R.; Williams, N.; Ellis, J.; Pitts-Singer, L.; Bommarco, R.; Vaughan, M. 2017.Integrated crop pollination:Combining strategies to ensure stable and sustainable yields of pollination-dependent crops. Basic Appl. Ecol., 22: 44-60.

IUCN. 2016. Guidelines for Appropriate Uses of IUCN Red List Data. Incorporating, as Annexes, the 1) Guidelines for Reporting on Proportion Threatened Species (ver. 1.1); 2) Guidelines on Scientific Collecting of Threatened Species (ver. 1.0); and 3) Guidelines for the Appropriate Use of the IUCN Red List by Business (ver. 1.0.). Version 3. Adopted by the IUCN Red List Committee, 3rd ed.; IUCN: Gland, Switzerland,; p. 32.

Jachuła, J.; Denisow, B.; Strzałkowska-Abramek, M. 2020. Does an invader have a bright side? Floral reward in two Solidago species. J. Apicult. Res..

Jacquemin, F.; Violle, C.; Munoz, F.; Mahy, G.; Rasmont, P.; Roberts, S.P.; Vray, S.; Dufrêne, M. 2020. Loss of pollinator specialization revealed by historical opportunistic data: Insights from network-based analysis.PLoS ONE, 15, e0235890.

Keeling, M.J.; Franklin, D.N.; Datta, S.; Brown, M.A.; Budge, G.E. 2017. Predicting the spread of the Asian hornet (Vespa velutina) following its incursion into Great Britain. Sci. Rep. UK, 7, 6240. 
Kennedy, C.M.; Lonsdorf, E.; Neel, M.C.; Williams, N.M.; Ricketts, T.H.; Winfree, R.; Bommarco, R.; Brittain, C.; Burley, A.L.; Cariveau, D.; et al. 2013. A global quantitative synthesis of local and landscape effects on wild bee pollinators in agroecosystems. Ecol. Lett., 16:584-599.

Koch, J.B.; Looney, C.; Sheppard, W.S.; Stange, J.P. 2017.Patterns of population genetic structure and diversity across bumble bee communities in the Pacific Northwest. Conserv. Genet.,18: 507-520.

Krechemer, F.S.; Marchioro, C.A. 2020. Past, present and future distributions of bumblebees in South America: Identifying priority species and areas for conservation. J. Appl. Ecol.

Kremen, C.; Iles, A.; Bacon, C. 2012. Diversified farming systems: An agroecological, systems-based alternative to modern industrial agriculture. Ecol. Soc., 17: 44.

La Vie Sauvage 2020. Emprunte Aussi nos Routes. Available online: http://biodiversite.wallonie.be/fr/la-viesauvage.html?IDC=3649 (accessed on 14 August).

Lane, I.; Portman, Z.M.; Cariveau, D.P. 2020.Floral resource diversity drives bee community diversity in prairie restorations along an agricultural landscape gradient. J. Appl. Ecol..

Laurino, D.; Lioy, S.; Carisio, L.; Manino, A.; Porporato, M. 2020. Vespa velutina: An Alien Driver of Honey Bee Colony Losses. Diversity, 12:5.

Lautenbach, S.; Seppelt, R.; Liebscher, J.; Dormann, C.F. 2012. Spatial and temporal trends of global pollination benefit. PLoS ONE, 7, e35954. [CrossRef] [PubMed]

Le Féon, V.; Aubert, M.; Genoud, D.; Andrieu-Ponel, V.; Westrich, P.; Geslin, B. 2018. Range expansion of the Asian native giant resin bee Megachile sculpturalis (Hymenoptera, Apoidea, Megachilidae) in France. Ecol. Evol., 8:1534-1542.

Lecocq, T.; Gérard, M.; Michez, D.; Dellicour, S. 2017. Conservation genetics of European bees: New insights from the continental scale. Conserv. Genet., 18:585-596.

Lecocq, T.; Michez, D.; Gérard, M.; Vereecken, N.J.; Delangre, J.; Rasmont, P.; Vray, S.; Dufrêne, M.; Mardulyn, P.; Dellicour, S. 2018.Divergent geographic patterns of genetic diversity among wild bees: Conservation implications. Divers. Distrib., 24:18601868.

Lopez-Uribe, M.M.; Soro, A.; Jha, S. 2017.Conservation genetics of bees: Advances in the application of molecular tools to guide bee pollinator conservation. Conserv. Genet., 18: 501-506.

Lowenstein, D.M.; Minor, E.S. 2016. Diversity in flowering plants and their characteristics: Integrating humans as a driver of urban floral resources. Urban. Ecosyst., 19:1735-1748.

Lozier, J.D.; Zayed, A. 2016. Bee conservation in the age of genomics. Conserv. Genet., 18:713-729.

Maclvor, J.S.; Packer, L. 2015. ‘Bee Hotels’ as Tools for Native Pollinator Conservation: A Premature Verdict? PLoS ONE, 10, e0122126.

Majewska, A.A.; Altizer, S. 2018. Planting gardens to support insect pollinators. Conserv. Biol., 34: 15-25.

Mallinger, R.E.; Franco, J.G.; Prischmann-Voldseth, D.A.; Prasifka, J.R. 2019. Annual cover crops for managed and wild bees: Optimal plant mixtures depend on pollinator enhancement goals. Agric. Ecosyst. Environ., 273:107-116.

Martins, K.T.; Gonzalez, A.; Lechowicz, M.J. 2015.Pollination services are mediated by bee functional diversity and landscape context. Agric. Ecosyst. Environ., 200:12-20.

Massaro, F.C.; Brooks, P.R.; Wallace, H.M.; Nsengiyumva, V.; Narokai, L.; Russel, F.D. 2013. Effect of Australian propolis from stingless bees (Tetragonula carbonaria) on pre-contracted human and porcine isolated arteries.PLoS ONE, 8, e81297.

Meeus, I.; Pisman, M.; Smagghe, G.; Piot, N. 2018. Interaction effects of different drivers of wild bee decline and their influence on host-pathogen dynamics. Curr. Opin. Insect. Sci., 26:136-141.

Moquet, L.; Vanderplanck, M.; Moerman, R.; Quinet, M.; Roger, N.; Michez, D.; Jacquemart, A.L. 2017. Bumblebees depend on ericaceous species to survive in temperate heathlands. Insect Conserv. Diver., 10:78-93.

Nichols, R.N.; Goulson, D.; Holland, J.M. 2019.The best wildflowers for wild bees. J. Insect. Conserv., 23:1-12.

Nicholson, C.C.; Egan, P.A. 2019. Natural hazard threats to pollinators and pollination. Glob. Chang. Biol.2019, 26:380-391.

Nowakowski, M.; Pywell, R.F. 2016. Habitat Creation and Management for Pollinators; Centre for Ecology \& Hydrology:Wallingford, $\mathrm{UK} ;$; p. 77.

Ollerton, J. 2017.Pollinator Diversity: Distribution, Ecological Function, and Conservation. Annu. Rev. Ecol.Evol. Syst., 48:353-376.

Packer, J.G.; Delean, S.; Kueffer, C.; Prider, J.; Abley, K.; Farcelli, J.M.; Carthew, S.M. 2016. Native faunal communities depend on habitat from non-native plants in novel but not in natural ecosystems. Biodivers.Conserv., 25:503-523.

Penn S. 2021."Climate change reduces the abundance and diversity of wild bees." ScienceDaily. ScienceDaily, 12 January 2021.

Pollinator Plan Steering Group. 2015. All-Ireland Pollinator Plan 2015-2020; National Biodiversity Data Centre Series No. 3; National Biodiversity Data Centre: Waterford, Ireland,; 48p, ISSN 2009-6844.

Potts, S.G.; Biesmeijer, J.C.; Kremen, C.; Neumann, P.; Schweiger, O.; Kunin, W.E. 2010. Global pollinator declines: Trends, impacts and drivers. Trends Ecol. Evol., 25:345-353.

Potts, S.G.; Imperatriz-Fonseca, V.; Ngo, N.T.; Aizen, M.A.; Biesmeijer, J.C.; Breeze, T.D.; Dicks, L.V.; Garibaldi, L.A.; Hill, R.; Settele, J.; et al. 2016. Safeguarding pollinators and their values to human well-being. Nature, 540:220-229.

Powney, G.D.; Carvell, C.; Edwards, M.; Morris, R.K.A.; Roy, H.E.; Woodcock, B.A.; Isaac, N.J.B. 2019.Widespread losses of pollinating insects in Britain. Nat. Commun., 10, 1018.

Primack, R.B.; Sarrazin, F.; Lecomte, J. 2012. Biologie de la Conservation; Dunord: Paris, France,

Quinet, M.; Mabeluanga, T.; Moquet, L.; Jacquemart, A.L. 2016. Introduction of new tools to improve pollination in European pear orchards. Sci. Hortic., 213: 5-12. 
Rader, R.; Bartomeus, I.; Garibaldi, L.; Garratt, M.P.D.; Howlett, B.; Cunningham, S.A.; Mayfield, M.M.; Arthur, A.D.; Andersson, G.K.S.; Bommarco, R.; et al. 2016. Non-bee insects are important contributors to global crop pollination. Proc. Natl. Acad. Sci. USA, 113:146-151.

Reemer, M. 2018. Basisrapport voor de Rode Lijst Bijen; EIS Kenniscentrum Insecten: Leiden, The Netherlands,; p. 174.

Ritchie, H.; Roser, M. 2020. "Crop Yields". Published online at OurWorldInData.org. Available online: https://ourworldindata.org/crop-yields (accessed on 14 August 2020).

Roger, N.; Moerman, R.; Carvalheiro, L.G.; Aguirre-Guitierrez, J.; Jacquemart, A.L.; Kleijn, D.; Lognay, G.;Moquet, L.; Quinet, M.; Rasmont, P.; et al. 2017. Impact of pollen resources drift on common bumblebees in NW Europe. Glob. Chang. Biol., 23:68-76.

Royal Mail. Royal Mail Issues Special Stamps Illustrating the Beauty of British Bees.

Sardiñas, H.S.; Kremen, C. 2014. Evaluating nesting microhabitat for ground-nesting bees using emergence traps. Basic Appl. Ecol., $15: 161-168$.

Säumel, I.; Weber, F.; Kowarik, I. 2016.Toward livable and healthy urban streets: Roadside vegetation provides ecosystem services where people live and more. Environ. Sci. Policy, 62:24-33.

Saunders, M.E.; Janes, J.; O'Hanlon, J. 2019.Moving on from the insect apocalypse narrative: Engaging with evidence-based insect conservation. BioScience.

Saunders, M.E.; Janes, J.; O’Hanlon, J. 2020. Semantics of the insect decline narrative; recommendations for communicating insect conservation to peer and public audiences. Insect Conserv. Diver., 13:211-213.

Saunders, M.E.; Smith, T.J.; Rader, R. 2018. Bee conservation: Key role of managed bees. Sciences, 360:, $381-389$.

Schatz, B.; Drossart, M.; Henry, M.; Geslin, B.; Allier, F.; Savajol, C.; Bellanger, S.; Michez, D. 2020. A boom of convergent information about the urgency to conserve pollinators. Acta Oecol., 105, (under major revision).

Schmitt, S.; Maréchaux, I.; Chave, J.; Fischer, F.J.; Piponiot, C.; Traissac, S.; Hérault, B. 2020. Functional diversity improves tropical forest resilience: Insights from a long-term virtual experiment. J. Ecol., 108: 831-843.

Schonfelder, M.L.; Bogner, F.X. 2017. Individual perception of bees: Between perceived danger and willingness to protect. PLoS ONE, $12, \mathrm{e} 0180168$.

Senapathi, D.; Goddard, M.A.; Kunin, W.E.; Baldock, K.C.R. 2017. Landscape impacts on pollinator communities in temperate systems: Evidence and knowledge gaps. Funct. Ecol., 31: 26-37.

Silva, A.; Minor, E.S. 2017. Adolescents' experience and knowledge of, and attitudes toward, bees: Implications and recommendations for conservation. Anthrozoos, 30.

Sivakoff, F.; Prajzner, S.P.; Gardiner, M.M. 2018. Unique bee community assembly within vacant lots and urban farms results from variation in surrounding landscape urbanization intensity. Sustainability, 10, 1926.

Smith, M.R.; Singh, G.M.; Mozaffarian, D.; Myers, S.S. 2015. Effects of decreases of animal pollinators on human nutrition and global health: A modelling analysis. Lancet, 386: 1964-1972.

Sobral-Souza, T.; Vancine, M.H.; Ribeiro, M.C.; Lima-Ribeiro, M. 2018. Efficiency of protected areas in Amazon and atlantic forest conservation: A spatial temporal view. Acta Oecologica, 87: 1-7.

Sutherland, W.J.; Barnard, P.; Broad, S.; Clout, M.; Connor, B.; Côté, I.M.; Dicks, L.V.; Doran, H.; Entwistle, A.C.; Esmail, N.; et al. 2016. Horizon scan of emerging issues for global conservation and biological diversity. Trends Ecol. Evol., 32:31-42.

Tanda AS 2020. Entpollinatology-a strong Relationship between plants and Insects for Crop Improvement. $6^{\text {th }}$ Edition of Global Conference on Plant Sciences and Molecular Biology (GPMB 2020)" to be held on September 10-12, 2020, at Paris, France. (Accepted, May 26, 2020).

Tanda AS 2021a. Comparative pollination efficacies of Apis mellifera L. and Tetragonula carbonaria (Smith) on peach (Prunus persica L.). Indian Journal Entomology (Accepted).

Tanda AS 2021b. Insect pollinators matter in sustainable world food production. Indian Journal Entomology (Accepted).

Tanda AS 2021c. Why insect pollinators important in crop improvement?. Indian Journal Entomology (Accepted).

Tanda AS. 2019. Entomophilous crops get better fruit quality and yield: An appraisal. Indian Journal Entomology 81(2): 227-234.

The Heinz Center. 2013. Pollinators and the State Wildlife Action Plans: Voluntary Guidance for State; Wildlife Agencies:Washington, DC, USA,; p. 20.

Tonietto, R.K.; Larkin, D.J. 2018.Habitat restoration benefits wild bees: A meta-analysis. J. Appl. Ecol., 55: 582-590.

Tosi, S.; Nieh, J.C. 2019. Lethal and sublethal synergistic effects of a new systemic pesticide, flupyradifurone (Sivanto), on honeybees. Proc. R. Soc. B Biol. Sci., 286, 2019433.

Turo, K.J.; Gardiner, M.M. 2019. From potential to practical: Conserving bees in urban public green spaces. Front. Ecol. Environ., $17: 167-175$.

Ubach, A.; Paramo, F.; Gutierrez, C.; Stefanescu, C. 2020. Vegetation encroachment drives changes in the composition of butterfly assemblages and species loss in Mediterranean ecosystems. Insect Conserv. Diver., 13:151-161.

un.org/development/desa/publications/2018-revision-of-world-urbanization-prospects.html (accessed on 14 August 2020).

Underwood, E.; Darwin, G.; Gerritsen, E. 2017. Pollinator Initiatives in EU Member States: Success Factors and Gaps. Report for European Commission under Contract for Provision of Technical Support Related to Target 2 of the EU Biodiversity Strategy to 2020-Maintaining and Restoring Ecosystems and Their Services; Institute for European Environmental Policy: Brussels, Belgium, ENV.B.2/SER/2016/0018.

Urbanowicz, C.; Muniz, P.A.; McArt, S.H. Honey bees and wild pollinators differ in their preference for and use of introduced floral resources. Ecol. Evol. 2020, 10:6741-6751. 
Valiente-Banuet, A.; Aizen, M.A.; Alcantara, J.M.; Arroyo, K.; Cocucci, A.; Galetti, M.; Garcia, M.B.; Garcia, D.;Gomez, J.M.; Jordano, P.; et al. 2015.Beyond species loss: The extinction of ecological interactions in a changing world. Funct. Ecol., 29:299-307.

Van Kleunen, M.; Weber, E.; Fischer, M. 2010. A meta-analysis of trait differences between invasive and non-invasive plant species. Ecol. Lett., 13: 235-245.

van Klink, R.; Bowler, D.E.; Gongalsky, K.B.; Swengel, A.B.; Gentile, A.; Chase, J.M. 2020. Meta-analysis reveals declines in terrestrial but increases in freshwater insect abundances. Science, 368:417-420. [PubMed]

Vaudo, A.D.; Farrell, L.M.; Patch, H.M.; Grozinger, C.M.; Tooker, J.F. 2018. Consistent pollen nutritional intake drives bumble bee (Bombus impatiens) colony growth and reproduction across different habitats. Ecol. Evol., 8:5765-5776.

Vaudo, A.D.; Tooker, J.F.; Grozinger, C.M.; Patch, H.M. 2015. Bee nutrition and floral resource restoration. Curr. Opin. Insect Sci., 10:133-141.

Ward, D.F. 2014. Understanding sampling and taxonomic biases recorded by citizen scientists. J. Insect. Conserv., 18: 753-756.

Warzecha, D.; Diekötter, T.; Wolters, V.; Jauker, F. 2016. Intraspecific body size increases with habitat fragmentation in wild bee pollinators. Landsc. Ecol., 31:1449-1455.

Waser, N.M.; Ollerton, J. 2006. Plant-Pollinator Interactions: From Specialization to Generalization; University of Chicago Press: Chicago, IL, USA.

Westrich, P.; Frommer, U.; Mandery, K.; Riemann, H.; Ruhnke, H.; Saure, C.; Voith, J. 2011. Rote Liste und Gesamtartenliste der Bienen (Hymenoptera, Apidae) Deutschlands (5. Fassung, Dezember 2011). Rote List. Gefährdeter Tiere Pflanz. Pilze Dtschl., 3 : 371-416.

Wilson, J.S.; Forister, M.L.; Carril, O.M. 2017. Interest exceeds understanding in public support of bee conservation. Front. Ecol. Environ., 15, 460-466. [CrossRef]

Wood, T.J.; Holland, J.M.; Goulson, D. 2015. Pollinator-friendly management does not increase the diversity of farmland bees and wasps. Biol. Conserv., 187: 120-126.

Wood, T.J.; Holland, J.M.; Goulson, D. 2017. Providing foraging resources for solitary bees on farmland: Current schemes for pollinators benefit a limited suite of species. J. Appl. Ecol., 54:323-333.

Wood, T.J.; Holland, J.M.; Hughes, W.O.; Goulson, D. 2015.Targeted agri-environment schemes significantly improve the population size of common farmland bumblebee. Mol. Ecol., 24:1668-1680.

Wood, T.J.; Michez, D.; Paxton, R.J.; Drossart, M.; Neumann, P.; Gérard, M.; Vanderplanck, M.; Barraud, A.; Martinet, B.; Leclercq, N.; et al. 2020.Managed honey bees as a radar for wild bee decline? Apidologie.

Woodard, S.H.; Lozier, J.D.; Goulson, D.; Williams, P.H.; Strange, J.P.; Jha, S. 2015. Molecular tools and bumble bees: Revealing hidden details of ecology and evolution in a model system. Mol. Ecol., 24: 2916-2936. 